\title{
Education and Human Rights
}

\author{
Güzver Yıldıran* \\ Boğaziçi University Faculty of Education Istanbul, Turkey \\ *Corresponding author: yildiran@boun.edu.tr \\ Received June 05, 2014; Revised June 16, 2014; Accepted June 22, 2014
}

\begin{abstract}
The contention presented in the paper is that there is no society in this day of globalization, where the institution of education is systematized within a moral or ethical frame aligned with the requirements stated in universal documents of human rights, signed by member states. Four points are emphasized and demonstrated by quantitative world data, where violations of human rights permeate educational systems across countries. The first violation of human rights is related to the question of who is allowed to be educated. The second human right violation is related to the differences in the in the duration of compulsory education and educational opportunities that exist in our world. The third human right violation is related to whether educational systems are based on social class differences, perpetuating inequalities at the societal level, for example as instantiated by Continental Europe. Finally, the fourth human right violation is presented in reltion to inequalities in the quality of compulsory education provided, where differences follow ethnic and racial demarcations, as instantiated by the United States of America.
\end{abstract}

Keywords: education, human rights, globalization

Cite This Article: Güzver Yıldıran, "Education and Human Rights." American Journal of Educational Research, vol. 2, no. 7 (2014): 456-462. doi: 10.12691/education-2-7-4.

\section{Introduction}

We live in an era which defines itself with the concept of globalization. Few terms of human conceptualization are as inclusive and unifying as that of globalization; yet few terms are capable of holding within their connotative boundaries the paradox of polarities and opposite actual practices. This article provides evidence from world data on the relationship between education and human rights.

Whether perceived as an exchangeable commodity or not in the age of globalization, the status of education in the world needs to be conceptualized within a broad explanatory paradigm which can account for human rights violations across countries, settings, and populations. The paradigm presented in this article has evolved from the tacit accumulation of problematic evidence noted by the author involved in education internationally as an academician, researcher, and administrator for more than 40 years. The frame presented, which has evolved through time, was then exposed to validity checks provided by international world data at intervals since the mid 1980's $[23,24]$. The present picture is painted from the most recent world data.

\subsection{General Frame}

If we look at the institution of education, we will not have to be geniuses to spot where we stand in the world. Yes, we screen for educational opportunities. We feel satisfied when our screening is reliable and valid. We make arrangements so that only the few who share the power structure of the status quo are able to surpass the screening. We ask the individual to be responsible to overcome the chance events of life in order to reach opportunities which guarantee satisfying levels of functionality and human dignity. We applaud those who, through some miraculous conglomeration of chance encounters, develop esteemed capacities. When children do not learn, we blame their genetic heritages and separate them into structures established in the dungeons of our hopes. In short, we put more effort into screening vast majorities out of education in the name of science than in enabling all human beings to perform at esteemed levels of functionality. Education as a universal human right seems to exist only on documents. That right is determined by the effect of chance events and our valid screening for the presence or absence of those events in the lives of human beings.

The following examples would suffice for the validity of the above stated affairs. Many countries in Africa, Asia, Australia, South America, and the Middle East are not capable of providing education for all of their children. Some provide just rudimentary education of no more than five years, which does not even encompass all. Other countries in Europe like Germany, the Netherlands, France and others track children at early ages (grade four in Germany, first year of secondary school in the Netherlands, when children are about nine and twelve years of age respectively), which in the end defines life opportunities of who will live how. Countries like the USA provide longer periods which are qualitatively different from setting to setting. I have had university level students in the USA who had reading difficulties and could not take percentages. In countries like mine (Turkey), there is a vast qualitative difference between the education given in selective institutions, public or private, and the regular state schools, even though the curricula are 
centralized. In other developed countries of Europe, as the educational level increases to higher education, the proportion of the population from the lower socioeconomic status levels represented falls drastically as in England, France, and Germany. What human right are we talking about anywhere in the world?

The profusion of research present in the infinite volumes of its accumulation seems only to foreshadow its proliferation into infinitely more volumes in the future. Somehow, this epistemological accumulation must become integrated and instrumental in the amelioration of the human condition. For unless knowledge and values have the common and universal aim of making a difference aligned with the concept of decency and dignity, our efforts will always be embedded in contradictions.

\section{Four Human Rights Violations in Education}

The contention in this article is that there is no society in this day of globalization, where the institution of education is systematized within a moral or ethical frame aligned with the requirements stated in universal documents of human rights signed by member states. Four points are emphasized, where violations of human rights permeate educational systems across countries. The first violation of human rights is related to the question of who is allowed to be educated. The second human right violation is related to the differences in the in the duration of compulsory education and educational opportunities that exist in our world. The third human right violation is related to whether educational systems are based on social class differences, perpetuating inequalities at the societal level, for example as instantiated by Continental Europe. Finally, the fourth human right violation points to inequalities in the quality of compulsory education provided, where differences follow ethnic and racial demarcations, as instantiated by the United States of America.

\subsection{Who Is Allowed to Be Educated}

Regarding the first human right violation of who is allowed to be educated, some statistics will be illustrative. Of the 650 million primary school-aged children in the world between the ages of 6-11, 115 million, in other words one out of every five children $(18 \%)$ is not in school. Forty five million of these children come from Africa, forming a disproportionate majority. Thus, one out of three unschooled children is from Africa. The second largest population of unschooled children is from Southern Asia, with 42 million youngsters not having the opportunity for compulsory primary education. The percentage outside of schooling process is $8 \%$ in the Middle East, 3\% in Central and Eastern Europe, and 2\% in industrial countries, [[4,22], p. 3], (Figure 1).

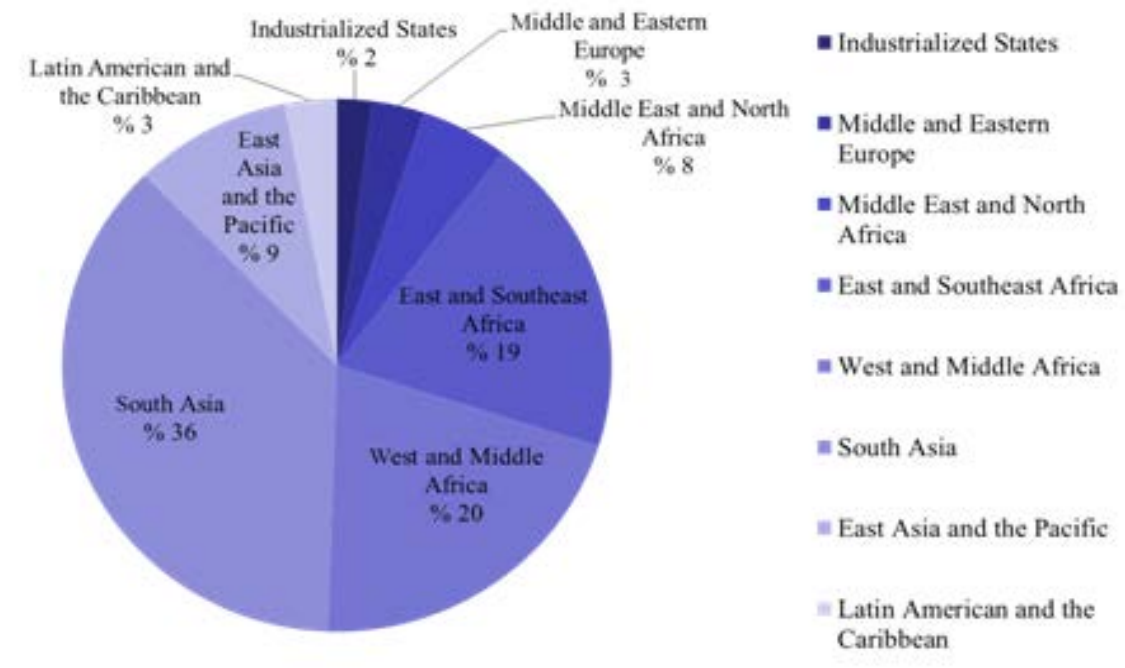

Figure 1. Percentages of Primary School-Aged Children Excluded from Education

Of primary school-aged children, 62 million girls and 54 million boys are excluded from schooling [[4,22], p. 3), (Figure 2).

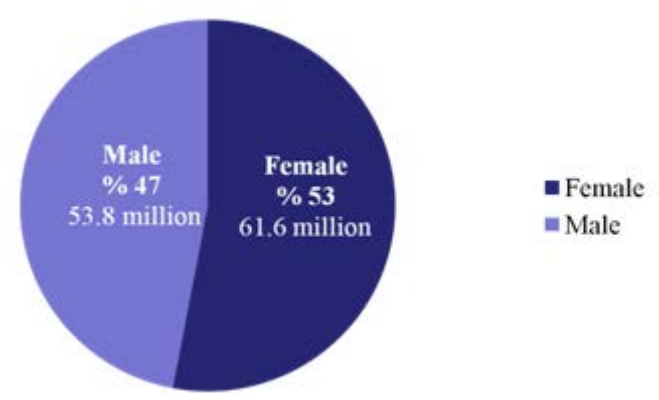

Figure 2. Gender Distribution of Children Excluded from Schooling Process at the Primary Education Level
The silent truth behind these statistics points to geographies of residence for the economically rich and the poor. This tragic picture is clearly an unacceptable violation of the universal right to education, where geographies of birth determine who will be educated.

\subsection{Duration of Compulsory Schooling}

The second violation regarding the right to education is related to the duration of compulsory schooling across countries. First, let us look at ages of starting primary education across countries as well as at percentages of atage population of beginning primary schooling. Out of 187 countries, children start primary education at the age of 6 in 119, and at 7 in 47 countries. Thus, 90\% of countries have their children start school at the age of 6 or 
7, (Figure 3). In terms of at-age population, $61 \%$ of world's primary school-aged children start school at 6 , $34 \%$ at 7 and $5 \%$ at 5 years of age. Thus, 95\% of the school-aged children in the world start school at the age of 6 or 7 , (Figure 4).
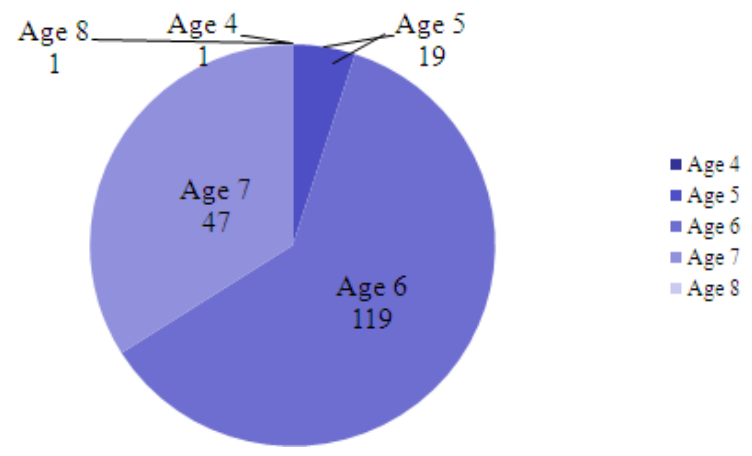

Figure 3. Ages of Starting Primary Education in the World (Ages 611/Number of Countries)
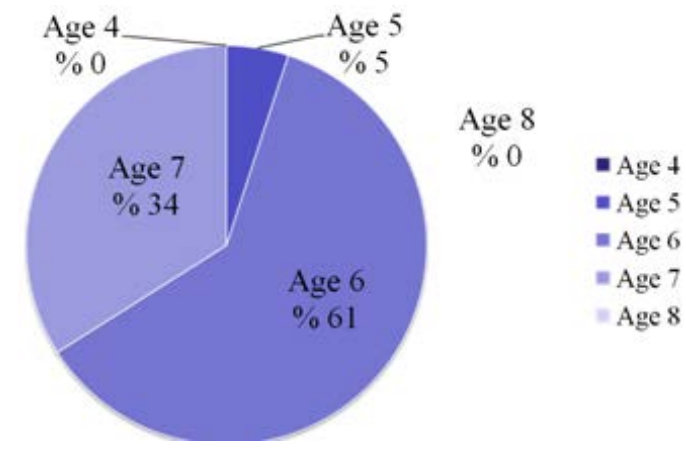

Figure 4. Ages of Starting Primary Education in the World (Ages 611/Percentage Rates Based on Population)

A law was passed in Turkey on March 30, 2012, restructuring levels of schooling on a $4+4+4$ model, with 4 years of primary, 4 years of middle or junior high, and 4 years of secondary schooling. According to this law, Turkish children had to start primary education at the age of 5.5 (66 months), which placed Turkey among the $10 \%$ of countries having children start school before the age of 6 , and Turkish children among the $5 \%$ of at-age population that start school at such an early age. This enactment differs from the experience of $95 \%$ of the world's at-age children, and does not overlap with $90 \%$ of other countries. However, the above stated law was modified on August 14, 2013, by the Ministry of National Education By-law for Institutions of Primary Education, in item 15 of Section 3, entitled Registration-Acceptance and Attendance. Item 15 states that, "66, 67 and 68 month-old children entitled to primary education can be directed to preschool education and defer registration to primary schools for one year by a petition from their guardians; while those who are 69, 70, and 71 months old can do the same by a medical certificate demonstrating that they are not ready for schooling.

Now, let us focus on the duration of compulsory education in the world. When we take the at-age primary school population as our base, $52 \%$ of children in the world have 5 years, $36 \% 6$ years, and $4 \% 7$ years of primary schooling. Thus, $92 \%$ of world's primary schoolaged children attend school for 5-7 years, with more than half having primary education for 5 , and $1 / 3$ for 6 years [[4], p. 15], (Figure 5).
If we take the number of countries as our index, out of 187 countries in 114 the duration of primary education is 6 years (61\%), in 22 countries 7 , in 19 countries 5 years. Two thirds of all countries have 6 years of primary education, and $82 \%$ have primary education for 5-7 years. As a country Turkey is among the $15 \%$ (29 countries) of countries which has four years of primary schooling. In terms of at-age population, Turkish children are in the 7\% of world's population of children with four years of primary education, [[4], p. 15], (Figure 6).

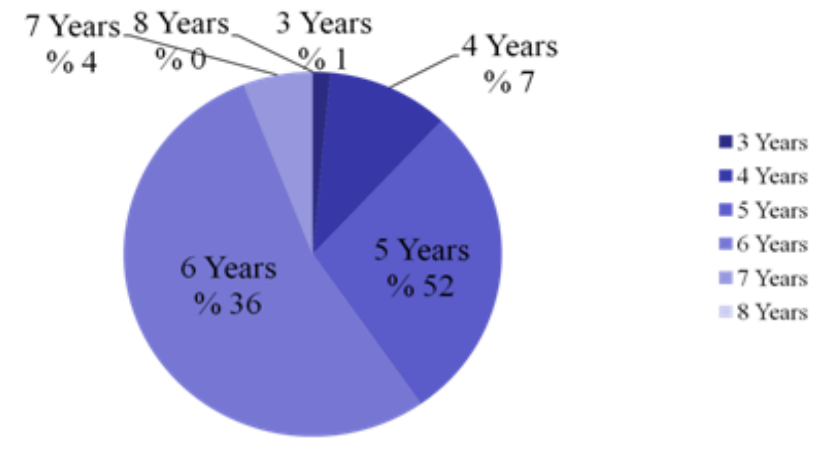

Figure 5. Duration of Primary Education in the World (Ages 611/Percentage Rates Based on Population)

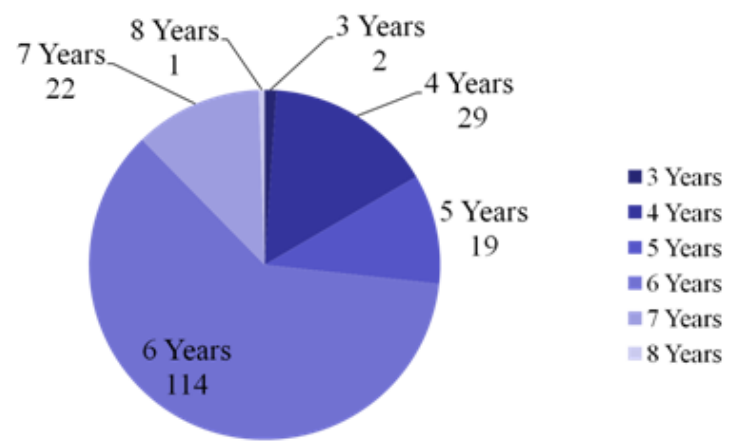

Figure 6. Duration of Primary Education in the World (Ages 6-11/ Number of Countries)

With these statistics, Turkey held a singular place in the world before the changes in August 2013, of children starting school at the age of 5.5, and finishing primary education 4 years later. The reason that primary schooling starts at the age of 6 or 7 and ends at 11 or 12 in a majority of countries is due to principles of psychology on human development. According to research on cognitive development based on the Piagetian paradigm, children start school when they are through the pre-operational period, and are capable of using concrete operations at the age of 6 or 7 . Sequentially, they start middle school when they start using formal operations, at the age of 11,12 .

Now let us briefly look at the Turkish educational system before and after 2012. Until 1997, schooling until higher education was divided into three levels of 5 years of primary, 3 years of middle, and 3 years of secondary schooling mostly state supported, where only the first 5 years were compulsory. In 1997, educational tiers were restructured into 8 years of compulsory state supported primary education, followed by 3 years of secondary schooling, again mostly state supported, [13]. In 2005, secondary schooling increased to 4 years, forming a model of 8 years of primary education including the middle school, and 4 years of secondary education. Under all of 
these arrangements, children started school at the age of six, when they were 72 months old. With the law of March 2012, another restructuring was enacted with 4 years of primary, 4 years of middle, and 4 years of secondary schooling, (Figure 7). We as educators and psychologists of Turkey hope that the duration of primary schooling will be at least 5 years, instead of 4 as stated by the law of March 2012. We are happy that the requirement of starting school at the age of 5 was modified through the revisions of August 2013, partly influenced by the chaos that parents, teachers, and students experienced at the beginning of the 2012-2013 academic year, as well as the contributions that educational scientists and psychologist shared with the public. Boğaziçi University was the first institution of higher education that responded to the law proposal, five days after it was shared with the public, on February 28, 2012.

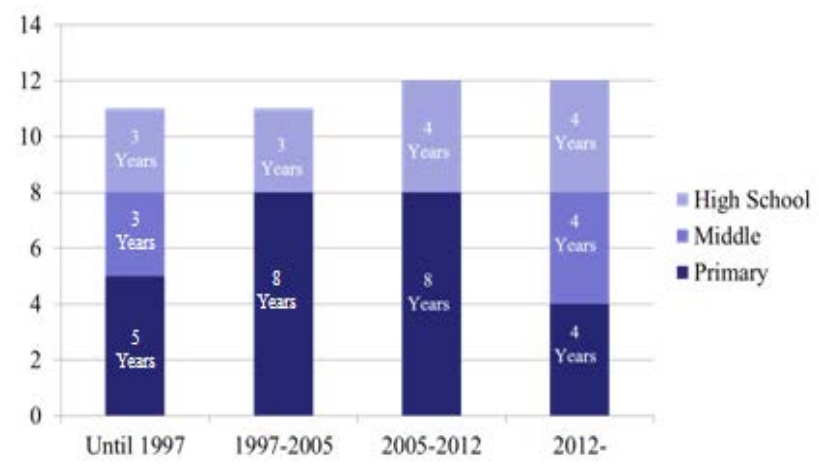

Figure 7. Levels of Schooling

Table 1. Number of Students and Schooling Ratios by Educational Level (8-year Compulsory Education) 2010-11

\begin{tabular}{|c|c|c|c|}
\hline $\begin{array}{c}\text { Level of } \\
\text { Education }\end{array}$ & $\begin{array}{c}\text { Number of Teachers/ } \\
\text { Teaching Staff }\end{array}$ & $\begin{array}{l}\text { Number of } \\
\text { Students }\end{array}$ & $\begin{array}{l}\text { Schooling } \\
\text { Ratio \% }\end{array}$ \\
\hline \multirow{3}{*}{$\begin{array}{l}\text { Primary } \\
\text { Education }\end{array}$} & Total: 503328 & $\begin{array}{c}\text { Total: } 10981 \\
100 \\
\end{array}$ & Total: 98.41 \\
\hline & & $\begin{array}{c}\text { Male: } 5623 \\
\quad 476 \\
\end{array}$ & Male: 98;59 \\
\hline & & $\begin{array}{c}\text { Female: } 5 \\
357624\end{array}$ & $\begin{array}{l}\text { Female: } \\
98,22\end{array}$ \\
\hline \multirow{3}{*}{$\begin{array}{l}\text { Secondary } \\
\text { Education }\end{array}$} & Total: 222705 & $\begin{array}{c}\text { Total: } 4748 \\
\quad 610 \\
\end{array}$ & Total: 69,33 \\
\hline & & $\begin{array}{l}\text { Male: } 2 \\
586171 \\
\end{array}$ & Male: 7135 \\
\hline & & $\begin{array}{c}\text { Female: } 2 \\
162439\end{array}$ & $\begin{array}{l}\text { Female: } \\
66.14\end{array}$ \\
\hline \multirow{3}{*}{$\begin{array}{l}\text { Higher } \\
\text { Education }\end{array}$} & Total: 111495 & $\begin{array}{c}\text { Total: } 3780 \\
\quad 916 \\
\end{array}$ & Total: 30.42 \\
\hline & Male: 65896 & $\begin{array}{l}\text { Male: } 2062 \\
\quad 318 \\
\end{array}$ & Male: 31,24 \\
\hline & Female: 45599 & $\begin{array}{c}\text { Female: } 1 \\
718598 \\
\end{array}$ & $\begin{array}{l}\text { Female: } \\
29: 55\end{array}$ \\
\hline
\end{tabular}

Table 1 [17] shows the numbers and percentages of students in primary, secondary and higher education in the academic year of 2010-2011 when primary education included middle schools. This was before the $4+4+4$ model was implemented in 2012. The tablo shows that about 11 million children were enrolled in primary education covering middle schools, comprising $98 \%$ of the at-age population in the nation, where there was no difference between male and female attendance. Seven youngsters of every 10 in the at-age population were in secondary education. At secondary school level there was somewhat of a sex bias favoring males, with $72 \%$ of the at-age male population attending secondary schools, while it was $66 \%$ for the female. At the tertiary level, 3 out of 10 youngsters of the at-age population in the nation attended institutions of higher education, where the sex bias was much less than that of secondary education, with 31\% atage male and $29.5 \%$ female population attending institutions of higher education. These data might indicate that the critical decision point of parents of female students was at the non-compulsory secondary school level. Once the decision for continuing with education was made at the secondary school level, the chances of having higher education for female students did not differ from that of males.

Table 2 [19] shows that in 2012 about 2 million students took the highly competitive centralized University Entrance Exams, 25\% being placed in an institution of higher education. Of the entering students, $88 \%$ were placed in state supported institutions, while $11.5 \%$ chose private institutions.

Table 2. Number of Universities and Entering Students

\begin{tabular}{|c|c|c|c|c|}
\hline & $\begin{array}{c}\text { Number of } \\
\text { Universities }\end{array}$ & $\begin{array}{c}\text { Total } \\
\text { Number } \\
\text { Taking } \\
\text { the Exam }\end{array}$ & $\begin{array}{c}\text { Available } \\
\text { Quota } \\
\text { (Undergrad) }\end{array}$ & $\begin{array}{c}\text { Percent of } \\
\text { Available } \\
\text { Quota For } \\
\text { Entering } \\
\text { Students }\end{array}$ \\
\hline Public & 109 & \multirow{2}{*}{$1,938,165$} & 469,686 & $\% 88.51$ \\
\cline { 1 - 2 } \cline { 5 - 5 } & 72 & 60,975 & $\% 11.49$ \\
\hline Private & 181 & & 530,661 & 100 \\
\hline Total & & &
\end{tabular}

In short of the 650 million primary school aged children, 115 million are excluded from education. As has been shown, the 535 million attending school have different durations of schooling. This becomes a human right problem in cases where compulsory primary schooling is the terminal stage in education, especially in countries where its duration is 4 or 5 years. It is unfortunately these countries that need qualified human power the most for development. Consequently, those countries for which education is most necessary end up with the least, forming a paradoxical deadlock.

\subsection{Education Structured on Social Class Differences}

The third human right violation occurs in countries where education is structured around social class differences. In such countries, schooling has the potential of consolidating social class and life style variations. Continental Europe reflects such structuring.

Table 3. Compulsory Education Durations in Various Countries Most of the European Union States (23 Countries) 19 or 10 years

\begin{tabular}{|c|c|}
\hline Luxemburg & 11 \\
\hline Malta & 11 \\
\hline England (UK) & 11 \\
\hline Wales (UK) & 11 \\
\hline Scotland (UK) & 11 \\
\hline Netherlands & 12 \\
\hline Northern Ireland (UK) & 12 \\
\hline
\end{tabular}

In most European countries, compulsory education is for 9 or 10 years until youngsters are 15 or 16 years of age. In Luxemburg, Malta, and England, Wales, and Scotland of the United Kingdom, compulsory education is for 11 years, in the Netherlands and Northern Ireland 12 years, and in Hungary 13 years, [[15], p. 41]. In the United States, which has a very different structure from Europe, compulsory education is for 12 years or is obligatory until the age of 16. Until the enactment of the March 2012 Law 
in Turkey, compulsory education was for 8 years, which is now extended to 12 years, (Table 3 ).

Table 4 [[12] p. 98; [18], p. 39-40; [11], p. 115; [10]] shows the average years of secondary and tertiary schooling in the European Union, OECD countries, and the United States.

Table 4. Percentage Rates of Completion of Secondary and Tertiary Tiers according to Country Populations of 25-64 Years of Age

\begin{tabular}{|c|c|c|c|c|c|}
\hline \multirow[t]{2}{*}{ Countries } & \multicolumn{2}{|c|}{$\begin{array}{c}\text { Completion of } \\
\text { Secondary } \\
\text { Education - Ages } \\
25-64 \% \\
\end{array}$} & \multicolumn{2}{|c|}{$\begin{array}{l}\text { Completion of } \\
\text { Higher Education } \\
\text { - Ages 25-64\% }\end{array}$} & \multirow{2}{*}{$\begin{array}{c}\begin{array}{c}\text { Average } \\
\text { Years of } \\
\text { Schooling }\end{array} \\
2012 \\
\end{array}$} \\
\hline & 1995 & 2009 & 2010 & 2011 & \\
\hline Germany & 84 & 85 & 23 & 26 & 12.2 \\
\hline Australia & 53 & 71 & 24 & 37 & 12 \\
\hline Austyria & 69 & 82 & 8 & 19 & 10.8 \\
\hline Belgium & 53 & 71 & 25 & 33 & 10.9 \\
\hline $\begin{array}{c}\text { Czech } \\
\text { Republic }\end{array}$ & 83 & 91 & 11 & 16 & 12.3 \\
\hline Denmark & 62 & 76 & 20 & 34 & 11.4 \\
\hline Finaland & 65 & 82 & 21 & 37 & 10.3 \\
\hline France & 68 & 70 & 19 & 29 & 10.6 \\
\hline Netherlands & 61 & 73 & 22 & 33 & 11.6 \\
\hline $\begin{array}{c}\text { United } \\
\text { Kingdom }\end{array}$ & 76 & 74 & 21 & 37 & 9.3 \\
\hline Spain & 28 & 52 & 16 & 30 & 10.4 \\
\hline Sweden & 75 & 86 & 28 & 33 & 11.7 \\
\hline Italy & 35 & 54 & 8 & 15 & 10.1 \\
\hline Canada & 75 & 88 & 47 & 50 & 12.1 \\
\hline Norway & 81 & 81 & 29 & 37 & 12.6 \\
\hline Portugl & 20 & 30 & 11 & 15 & 7.7 \\
\hline Greece & 43 & 61 & 17 & 24 & 10.1 \\
\hline Turkey & 12 & 31 & 7 & 13 & 6.5 \\
\hline OECD & 62 & 73 & 21 & 30 & \\
\hline $\mathrm{EU}$ & & 75 & & 27 & \\
\hline USA & 86 & 89 & 33 & 41 & 12.4 \\
\hline
\end{tabular}

As is seen, $73 \%$ of the 25-64 year-old population has completed secondary education in OECD countries, 75\% in countries of the Eropean Union, and 89\% in the United States. Turkey with $31 \%$ completing secondary education rates second to the last, before Portugal. In higher education, $30 \%$ of the population has completed the tertiary level in the OECD countries, 27\% in the European Union, and $41 \%$ in the United States. Turkey with $13 \%$ rates among the last, again close to Italy and Portugal. One notes that the European Union comprised of developed countries shows within itself rather large variations in terms of accessibility to higher education. The table silently indicates the amount of effort required in our world for equity of educational opportunities.

At the macro level, what is problematic in Europe is not so much the duration of secondary schooling. It is rather the tracking of students into different categories of types of schooling, which reflects rather clearly social class demarcations. In these countries while almost all of the atage population is in school, the type of school attended reflects social class biases. Papadopoulos [[20], p. 99] states that in Europe vocational technical education is for the lower middle class, while university preparatory gymnasium education is for the children of professional classes. This is more the case in Continental Europe than in the Scandanavian countries, $[14,16]$.

In most countries of the European Union, students share a core curriculum until the age of 14-15, equivalent to the beginning of high school education in Turkey. In the United Kingdom, Malta, Poland, Finland, Denmark, Sweden, Norway and Estonia, the core curriculum is effective until $10^{\text {th }}$ grade, when students are 16 years old.
On the other hand, in the Chech Republic, Latvia, Hungary, and Slovakia, students can be channeled into different tracks at the age of 10 or 11, [[15], p. 42]. The two countries which track their children very early at the age of 10 are Germany and Austria. Among countries of early tracking are the Netherlands which tracks children at the age of 11-12, Liechtenstein at 11 and Luxemburg at 12, [[15], p. 42], (Table 5).

Table 5. Ages of Completion of the Core Curriculum in the European Union Countries

\begin{tabular}{|c|c|}
\hline $\begin{array}{c}\text { Most of the European Union Countries (16 } \\
\text { Countries) }\end{array}$ & $\begin{array}{c}\text { Until the Age of 14- } \\
15\end{array}$ \\
\hline Czech Republic & 15 \\
\hline Portugal & 15 \\
\hline Slovenia & 15 \\
\hline Slovakia & 15 \\
\hline United Kingdom & 16 \\
\hline Malts & 16 \\
\hline Poland & 16 \\
\hline Finland & 16 \\
\hline Denmark & 16 \\
\hline Sweden & 16 \\
\hline Norway & 16 \\
\hline Estonia & 16 \\
\hline
\end{tabular}

In Turkey between 1997 and 2012, students had compulsory education with a core curriculum until the end of $8^{\text {th }}$ grade, after which they would take centralized examinations to enter selective public or private schools and vocational-technical education. With the law of 2012, compulsory education increased to 12 years with the option of going into religious seminaries in middle school after the completion of fourth grade. Approximately $2 \%$ of students choose this option. Students may choose to take examinations for selective public or private secondary schools, as well as vocational technical education after the completion of middle school.

One of the advantages of a continuous core curriculum is the reduction in the rate of dropouts or attrition that occurs when students change tracks and schools. A continuous core curriculum is especially advantageous for risk groups which might be excluded from higher levels of education, such as those that come from low socioeconomic levels, girls, and students with special needs. Secondly, a common and continuous curriculum has the likelihood of reducing the differences in achievement levels due to socio-economic status.

Table 6. Inequalities in Achievement at 10 and 15 Years of Age

\begin{tabular}{|c|c|c|}
\hline & At the Age of 10 & At the Age of 15 \\
\hline 1 & New Zealand & Germany \\
\hline 2 & TURKEY & New Zealand \\
\hline 3 & USA & Greece \\
\hline 4 & Norway & Norway \\
\hline 5 & Iceland & USA \\
\hline 6 & Greece & \\
\hline 7 & Canada & Iceland \\
\hline 8 & Italy & France \\
\hline 9 & France & Sweden \\
\hline 10 & Slovakia & Czech Republic \\
\hline 11 & Germany & TURKEY \\
\hline 12 & Hungary & Slovakia \\
\hline 13 & Sweden & Russia \\
\hline 14 & Russia & Hungary \\
\hline 15 & Czech Republic & Letoonia \\
\hline 16 & \multicolumn{2}{|c|}{ Hongkong Canada } \\
\hline 17 & Letoonia & Hongkong \\
\hline 18 & Netherlands & Netherlands \\
\hline
\end{tabular}

A study done in 2005 including 18 countries [9] showed interesting results. In terms of the magnitude of 
differences in achievement among 10 year-old children of low and high socio-economic status, New Zealand was first, while Turkey was second. However at the age of 15, in terms of variances in achievement of children coming from different socio-economic status, Germany which does the earliest tracking at the age of 10 rated the first, the United States the $5^{\text {th }}$, and Turkey which at the time had 8 years of continuous compulsory education closed the differences and rated the $11^{\text {th }}$, (Table 6).

In the German educational system as well as that in the Netherlands, there are three different types of schools into which students are tracked. The pre-university track gymnasium in Germany and the VWO in the Netherlands are mostly for the children of elite or professional classes; the vocational-technical Realschule in Germany and HAVO in the Netherlands include children of middle and lower middle class families; while Hauptschule in Germany, and vocational training in the Netherlands for youngsters between the ages of 12-16, teaching the skills to be a good citizen is for the lowest socio-economic classes and immigrant children.

Table 7 reduces the population of the first 12 countries of the European Union to 100 people, and shows professional and socio-economic mobility of parents and their offspring [[8], p. 140]. The table clearly illustrates that upward social mobility is rather guarded in Europe, and the offspring usually stay within the social class boundaries of their parents.

Table 7. Parental Social Class and Indrvidual's Social Class

\begin{tabular}{|c|c|c|c|c|}
\hline Family Status & $\begin{array}{c}\text { Professional } \\
\text { Class }\end{array}$ & $\begin{array}{c}\text { Middle } \\
\text { Class }\end{array}$ & $\begin{array}{c}\text { Working } \\
\text { Class }\end{array}$ & Total \\
\hline $\begin{array}{c}\text { Professional } \\
\text { Class }\end{array}$ & 5 & 4 & 1 & 10 \\
\hline Middle Class & 8 & 20 & 12 & 40 \\
\hline Working Class & 2 & 21 & 27 & 50 \\
\hline Total & 15 & 45 & 40 & 100 \\
\hline
\end{tabular}

Another topic that needs to be questioned is why vocational technical education, very much needed after the Second World War as countries were rebuilding their futures from the remnants of destruction with hopes that stemmed from the contribution of their civilization to humanity, did not become obsolete despite evidence? Today, science produces new information, evolving into new technologies and informatics systems, changing, extending, and transforming our lives everyday. The rapid change of knowledge and technology requires educational systems that develop transfer skills to new situations rather than the teaching of specific skills, which will most likely be obsolete in rather short time intervals. The best vocational-technical education, thus, becomes a very good general education of 12 years, capable of helping the individual to adapt to epistemological and ethical requirements of changing societies. Choices of careers at the higher education tiers will then hopefully be more rational as well as economical.

These data show human rights violations in Europe regarding educational systems. Three different types of schooling in countries which have low upward mobility has the likelihood of confining people into stable social class structures, increasing the variation in levels of achievement at school and lifespan functionality levels in society. Secondly, research in educational sciences has shown that levels of functionality as well as interest at the ages of $10-12$ or even $15-18$ are not stable. Levels of achievement and interest are highly dependent on the structuring of learning environments and the provision of absent prerequisites of learning, as pivotal contributions of Benjamin Bloom [1,2,3,5,6,7] of the United States and Reuven Feuerstein of Israel have shown. To orient children into tracks of education which will define their lifespan functionality levels, particularly at a time they are most changeable in terms of their cognitive, affective and social interests, skills and knowledge seems not only to violate scientific findings, but is also against the concept of equality of opportunity, the principle sine qua non of democracies.

\subsection{Local Resources and Ethnic and Racial Demarcations}

Now, let us focus on the fourth human rights violation in education related to differences in achievement levels, reflecting ethnic and racial demarcations. The example of illustration is the United States, which has a different educational system from European countries. Compulsory general education is for 12 years in the United States, without the existence of different tracks. This is indicative of efforts to enhance equality of opportunity, based on the foundation of democratic political ideals. Thus, 9 people out of 10 between the ages of 25-64 have completed 12 years of secondary general education, and 2 people out of 5 have completed higher education in the US (Table 4). Thus, in terms of schooling ratios, number of years of schooling and the availability of general education to the whole population, the United States presents a more democratic profile. Because there is a wide variety of higher educational institutions and criteria of selection, a common decision for admittance is reached based on alternatives available to the student and the higher education institution. Who applies to which higher education institution comprises the first step of admittance to a higher education institution. The student then selects the most appropriate institution of higher education from among the acceptances sent by universities. Alternatives are still open to the student related to major areas of study, which may change during the first two years according to alterations and modifications in interests and acquired knowledge or skills. Ergo, professional decisions are formed at various steps along the way. The process is desirable in terms of the availability of alternatives to the individual.

Despite these opportunities, has the United States of America solved its problems related to education? As has been expressed before, no country has reached desired levels of functionality aligned with human rights in education. Education is managed locally, not centrally in the US. The financially strong communities therefore have better educational opportunities in comparison to economically disadvantaged communities. There are vast incomparable differences between the standards and educational outcomes of economically dissimilar communities. The family background of the individual determines where the person lives. Where the person lives has great influence on the quality of education received. Thus, wide variations in achievement occur for reasons different from those in Europe. Regional and local inequalities in educational opportunities and outcomes 
unfortunately become structured on the bases of ethnic and racial differences due to localities of residence.

Table 8 [[21], p. 25] shows the difference between Afro-American and white American students vis à vis equality of later opportunities. The table shows that when on the average 2500 dollars are spent per student, in order to have equal opportunities later on in life, 12,000 dollars have to be spent for the Afro-American child as opposed to 1200 dollars for the white child. This of course is a hypothetical situation of what should be done if society is interested in equality of opportunity for all of its members.

Table 8. Educational Expenditures for Equality of Opportunity in USA

\begin{tabular}{|c|c|c|}
\hline $\begin{array}{c}\text { Expenditure per } \\
\text { Student }\end{array}$ & $\begin{array}{c}\text { Afro-American } \\
\text { Students }\end{array}$ & $\begin{array}{c}\text { White-American } \\
\text { Students }\end{array}$ \\
\hline$\$ 2500$ & $\$ 12,000$ & $\$ 1204$ \\
\hline$\$ 3950$ & $\$ 14,538$ & $\$ 2506$ \\
\hline
\end{tabular}

\section{Final Comments}

As has been said before, in an era of rapid developments in science, technology, and economics, education as an institution and process has fallen short of initiating and providing desirable changes affecting humanity. As an institution, education has not been able to be all inclusive in economically impoverished countries, has reproduced, and for marginalized groups has increased social class biases in Europe, while in the US has been largely oblivious to the proliferation of structures that augment differences between the rich and the poor along ethnic and racial demarcations.

To diagnose the problem is the first step toward its solution. If we are aware of the principles upon which societies can enhance life, and if we value inclusive paradigms that show respect for the dignity of every human being, we can formulate desirable processes even in education, with which life on our planet can be enriched. This will of course require great effort in reformulating our priorities.

As an educational psychologist that has worked on educational problems for more than forty years, I would like to share with you my hopes for and my faith in education as a system, institution and process, having pivotal potential for the actualization of the goals of our dreams.

\section{References}

[1] Bloom, B. S. (1964). Stability and change in human characteristics. New York: John Wiley \& Sons, Inc.

[2] Bloom, B. S. (1976). Human characteristics and school learning. New York: McGraw-Hill.

[3] Bloom, B. S. (Ed.). (1985). Developing talent in young people. New York: Ballantine Books.
[4] Children Out of School: Measuring Exclusion from Primary Education (2005). Montreal, Quebec, Canada: UNESCO Institute for Statistics.

(http://www.uis.unesco.org/Library/Documents/oosc05-en.pdf).

[5] Feuerstein, R. (1979). The Dynamic Assessment of Retarded Performers: The Learning Potential Assessment Device, Theory, Instruments, and Techniques. Baltimore: University Park Press.

[6] Feuerstein, R. (1985). Instrumental Enrichment: An Intervention Program for Cognitive Modifiability. Baltimore: University Park Press.

[7] Feuerstein, R., Klein, P.S., Tannenbaum, A.J. (Eds.; 1991). Mediated Learning Experience (MLE): Theoretical, Psychosocial and Learning Implications. London: Freund Publishing House Ltd.

[8] Girod, R. (1980). Goals and results. In Educational Goals. Paris: UNESCO, 123-144.

[9] Hanushek, E. A. and Wößmann, L. (2005). Does Educational Tracking Affect Performance and Inequality? Differences-inDifferences Evidence across Countries. The Economic Journal, 116, 63-76.

[10] HDRO updates of Barro and Lee (2010) estimates based on UNESCO Institute for Statistics data on education attainment (2011) and Barro and Lee (2010) methodology.

[11] Higher Education in Developing Countries: Peril and Promise (2000). Washington D.C.: The Task Force on Higher Education and Society, The International Bank for Reconstruction and Development/The World Bank.

[12] Human Capital Investment: An International Comparison (1998). Paris: Organisation for Economic Co-operation and Development, OECD: Centre for Educational Research and Innovation.

[13] Human Development Report: Turkey (1997). Ankara: United Nations Development Programme.

[14] Husén, T. (1990). Education and the Global Concern. New York: Pergamon Press.

[15] Key Data on Education in Europe 2009 (July 2009). Brussels: European Commission, Education, Audiovisual \& Culture Executive Agency, Eurydice, Eurostat. (http://eacea.ec.europa.eu/education/eurydice/documents/key_data _series/105EN.pdf).

[16] Markland, S. (1985). The Western European idea in education. In Contemporary Issues in Comparative Education. Watson, K. and Wilson, R. (Eds.). London: Croom Helm, 106-116.

[17] MEB (Mart 2011). Milli Eğitim İstatistikleri Örgün Eğitim 20102011.

http://sgb.meb.gov.tr/istatistik/meb_istatistikleri_orgun_egitim_20 10_2011.pdf

[18] OECD (2011). Education at a Glance 2011: OECD Indicators. OECD Publishing. (http://www.oecd.org/dataoecd/61/2/48631582.pdf)

[19] ÖSYM (2012). 2012-Lisans Yerleştirme Sınavları (2012-LYS) Sonuçları. http://www.osym.gov.tr/dosya/1-60607/h/2012lyssayisalbilgiler23072012.pdf

[20] Papadopoulos, G.S. (1994); Education 1960-1990: The OECD Perspective. Paris: OECD.

[21] Roemer, J.E. (2000). Equality of opportunity. In Meritocracy and Economic Inequality. Arrow, K., Bowles, S., and Durlauf, S. (Eds.). Princeton, New Jersey: Princiton University Press, 17-32.

[22] Wright, C., Chief of Education, UNICEF, Millward, M., Director, a.i. UNESCO Institute for Statistics (2005). Foreword. In Children Out of School: Measuring Exclusion from Primary Education (2005). Montreal, Quebec, Canada: UNESCO Institute for Statistics. (http://www.uis.unesco.org/Library/Documents/oosc05en.pdf).

[23] Yıldıran, G. (1996). Değişen dünyada eğitimimiz: Olgular, seçenekler.Eğitimimiz ve Türkiye'de Zorunlu Temel Eğitim. Bașak, O., Doltaş, D., (Eds.). İstanbul: Ilıcak Gazetecilik ve Matbaacılık A.Ş., 73-89.

[24] Yıldıran, G. (1999). Değişen dünyada eğitimimiz: Olgular, seçenekler. Eğitim ve Bilim, Vol. 24, No. 114, 39-51. 